\title{
Performance of allogeneic bioengineered replacement pulmonary valves in rapidly growing young lambs
}

\author{
Rachael W. Quinn, PhD, Arthur A. Bert, MD, Gabriel L. Converse, PhD, Eric E. Buse, MS (BME), \\ Stephen L. Hilbert, PhD, MD, William B. Drake, MD, MS, and Richard A. Hopkins, MD
}

\begin{abstract}
Background: Cardiac allometric organ growth after pediatric valve replacement can lead to patient-prosthesis size mismatch and valve re-replacement, which could be mitigated with allogeneic decellularized pulmonary valves treated with collagen conditioning solutions to enhance biological and mechanical performance, termed "bioengineered valves." In this study, we evaluated functional, dimensional, and biological responses of these bioengineered valves compared with traditional cryopreserved valves implanted in lambs during rapid somatic growth.
\end{abstract}

Methods: From a consanguineous flock of 13 lambs, the pulmonary valves of 10 lambs (mean weight, $19.6 \pm 1.4 \mathrm{~kg}$ ) were replaced with 7 bioengineered valves or 3 classically cryopreserved valves. After 6 months, the 10 lambs with implanted valves and 3 untreated flock mates were compared by echocardiography, cardiac catheterization, and explant pathology.

Results: Increases in body mass, valve geometric dimensions, and effective orifice areas were similar in the 2 groups of lambs. The bioengineered valves had higher median cusp-to-cusp coaptation areas $(34.6 \%$; interquartile range, $21.00 \%-35.13 \%)$ and were more similar to native valves $(43.4 \%$; interquartile range, $42.59 \%-44.01 \%$ ) compared with cryopreserved valves ( $13.2 \%$; interquartile range, $7.07 \%-13.91 \%)(P=.043)$. Cryopreserved valves cusps, but not bioengineered valve cusps, were thicker than native valve cusps $(P=.01)$. Histologically, cryopreserved valves demonstrated less than native cellularity, whereas bioengineered valves that were acellular at the time of surgery gained surface endothelium and subsurface myofibroblast interstitial cells in pulmonary artery, sinus wall, and cusp base regions.

Conclusions: Biological valve conduits can enlarge via passive dilatation without matrix synthesis, but this would result in decreased cusp coaptational areas. Bioengineered valves demonstrated similar annulus enlargement as cryopreserved valves but usually retained larger areas of cuspal coaptation. Heat-shock protein 47-positive (collagen-synthesizing) cells were present in previously acellular bioengineered sinus walls and cusp bases, but rarely in more distal cusp matrices. (J Thorac Cardiovasc Surg 2016;152:1156-65)

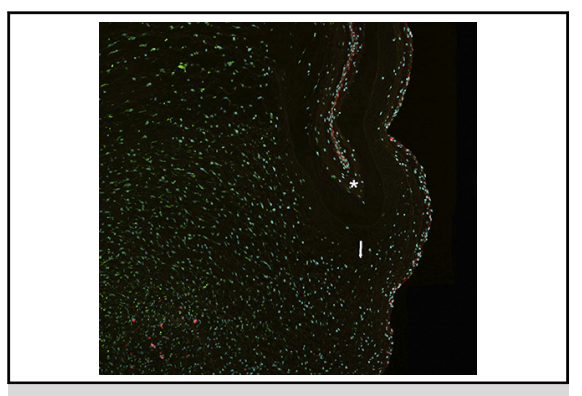

BEPV recellularization at 6 months after surgery: $\downarrow$ sub-base. *Sinus wall-leaflet junction.

\section{Central Message}

Bioengineered valves maintain larger cusp closure coaptation areas compared with cryopreserved valves during 6 months of rapid somatic growth

\section{Perspective}

Failure modes for homograft valved conduits include calcific tissue degradation and progressive size mismatch. Allogeneic valves can be decellularized to remove the majority of donor antigenic epitopes to reduce immuneinflammatory degradation. Collagen conditioning without cross-linking may restore extracellular matrix remodeling capacity (ie, structural protein turnover) after recellularization.

See Article page 1197

See Editorial Commentaries page 1165, 1200 , and 1202 .
Bioengineering of allogeneic heart valve scaffolds for pediatric valve replacement has been pursued with the

From Cardiac Regenerative Surgery Research Laboratories, Ward Family Heart Center/Cardiothoracic Surgery, Children's Mercy Kansas City, Kansas City, Mo. Read at the 41st Annual Meeting of The Western Thoracic Surgical Association, Whistler, British Columbia, Canada, June 24-27, 2015.

Received for publication Feb 23, 2016; revisions received May 3, 2016; accepted for publication May 8, 2016.

Address for reprints: Richard A. Hopkins, MD, Cardiac Regenerative Surgery Research Laboratories, Ward Family Heart Center/Cardiothoracic Surgery, Children's Mercy Kansas City, Kansas City, MO 64108 (E-mail: rahopkins@cmh.edu). 0022-5223/\$36.00

Copyright (c) 2016 by The American Association for Thoracic Surgery

http://dx.doi.org/10.1016/j.jtcvs.2016.05.051 intention of increasing durability over currently available valved conduits. ${ }^{1}$ To the extent that autologous in vivo recellularization with valve interstitial cells occurs, there is the theoretical potential for constructive and adaptive vascular tissue matrix remodeling. ${ }^{2}$ Cryopreserved

Scanning this QR code will take you to supplemental figures, tables, and video for this article.

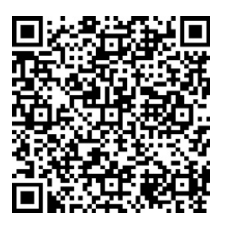



Abbreviations and Acronyms
$\alpha$-SMA $=$ alpha smooth muscle actin
BEHV = bioengineered heart valve
BEPV = bioengineered pulmonary valve
BSA = body surface area
CryoV $=$ cryopreserved valve
$\mathrm{ECM}=$ extracellular matrix
EOA $=$ effective orifice area
$\mathrm{H} \& \mathrm{E}=$ hematoxylin and eosin
HSP-47 = heat-shock protein 47
PA $=$ pulmonary artery
PCNA = proliferating cell nuclear antigen
$\mathrm{PV}=$ pulmonary valve
RVOT = right ventricular outflow tract
TEE $=$ transesophageal echocardiography
VEC = valve endothelial cell
VIC = valve interstitial cell
$\mathrm{vWF}=$ von Willebrand factor

allograft valves are known to result in inflammation and an acellular matrix owing to donor cell necrosis and apoptosis, ultimately failing from calcific degradation. ${ }^{3}$ None of the currently available clinical valve replacement options exhibits allometric enlargement synchronous with the child's somatic growth; therefore, multiple replacements are typically needed. ${ }^{4-7}$ With cardiovascular conduits, growth versus passive dilatation is difficult to distinguish, and persistence of seeded cells has not been proven. ${ }^{8,9}$ Thus, evidence for the concept that longer-term function is improved due to extracellular matrix (ECM) synthesis enabled by progressive in vivo recellularization of heart valves, either by cell migration via bioengineered enhanced cell homing or by the maturation of a cell population initiated ex vivo by tissue engineering (ie, bioreactor cell seeding), has proven elusive. $^{10,11}$

Our group has pursued a replacement pulmonary valve conduit by first decellularizing allogeneic semilunar donor valves and then conditioning the acellular collagen/elastin scaffold with solutions designed to restore viscoelasticity and improve cell-compatible biological properties. ${ }^{12-15}$ We term these bioengineered heart valves (BEHVs), because they are treated with adherence to bioengineering principles, and should be distinguished from bioreactor cell seeded tissueengineered valves (TEHVs). ${ }^{16,17}$ This study was performed to examine the hypothesis that surgically implanted BEHVs are capable of autologous reendothelialization and at least partial recellularization of the valve matrix in vivo and maintain better cusp closure mechanics during robust somatic growth and valve enlargement.

\section{MATERIALS AND METHODS \\ Animals}

All animal procedures were approved by the Institutional Animal Care and Use Committee. Humane care was provided in compliance with the National Institutes of Health's Guide for Care and Use of Laboratory Animals. Ten ewe lambs were implanted with cryopreserved pulmonary allografts (CryoV; $\mathrm{n}=3)$ or decellularized and ECM preimplantation conditioned pulmonary allografts (BEPV; $n=7)$. Three additional unoperated age-matched herdmates (native) were kept with the surgical animals for somatic growth and terminal hemodynamic comparisons.

For the procurement of donor valves, male cross-bred sheep from nonrelated flocks were euthanized, and 10 pulmonary valves (mean size, $17.8 \pm 1.4 \mathrm{~mm}$ ) were harvested using sterile technique (warm ischemia $<1$ hour), then cryopreserved using clinically analogous protocols ${ }^{18}$ in $10 \%$ dimethyl sulfoxide (Sigma-Aldrich, St Louis, Mo) in RPMI-1640 medium (Gibco, Carlsbad, Calif). ${ }^{18}$

\section{Decellularization and ECM Conditioning}

To prepare BEPVs, CryoVs were decellularized as described previously using reciprocating osmolality, 2 nondenaturing detergents (n-lauroyl sarcosine and Triton-X; Sigma-Aldrich), recombinant endonuclease, and multiple solvents (saline, water, and ethyl alcohol), after which they were re-cryopreserved using $10 \%$ dimethyl sulfoxide. ${ }^{12}$ Conditioning of the decellularized valves was performed in the operating room as a 2-step procedure, with 60 minutes of immersion in hypertonic saline/mannitol solution followed by 15 minutes of immersion in a unique fatty alcohol with recombinant human hyaluronin solution designed to acidify and strengthen the reversible collagen hydrogen bonding, infiltrate a soluble ECM proteoglycan, reduce collagen fraying, and act as an emollient/lubricant. $^{13,14}$

\section{Surgical Methods}

Via a left thoracotomy, anesthetized animals were placed on cardiopulmonary bypass. Replacement valves were interposed between the right ventricular outflow tract (RVOT) and pulmonary artery (PA) bifurcation after removal of the native pulmonary valve (PV) and PA. Proximal and distal oblique anastomoses were constructed with running polypropylene sutures.

\section{Cardiac Imaging and Measurements}

Transesophageal echocardiography (TEE) was performed to evaluate replacement valve hemodynamic performance at surgery and in a blinded format on the day of explant (6 months postimplantation). Measurements were obtained both at sedated baseline and at a maximum cardiac output achieved via dobutamine administration. ${ }^{19,20}$ Two-dimensional images for dimensions (Figure E1) and Doppler-derived hemodynamic measurements were captured digitally (X7-2T probe; Philips, Amsterdam, The Netherlands). Pressure gradients were calculated by a modified Bernoulli equation.

Valve regurgitation was evaluated by color flow Doppler and graded as none $(0$, no regurgitant jet), trace $(1+$, regurgitant jet limited to immediate valve vicinity), mild ( $2+$, regurgitant jet limited to RVOT), moderate (3+, regurgitant jet extending into right ventricular cavity), or severe $(4+$, regurgitant jet extended to tricuspid valve). A 6-Fr catheter was advanced via the femoral vein to the heart chambers for simultaneous pressure measurements (PX272 transducer; Edwards Lifesciences, Irvine, Calif). Transvalvular pressure gradients, regurgitation, leaflet motion, ventricular 


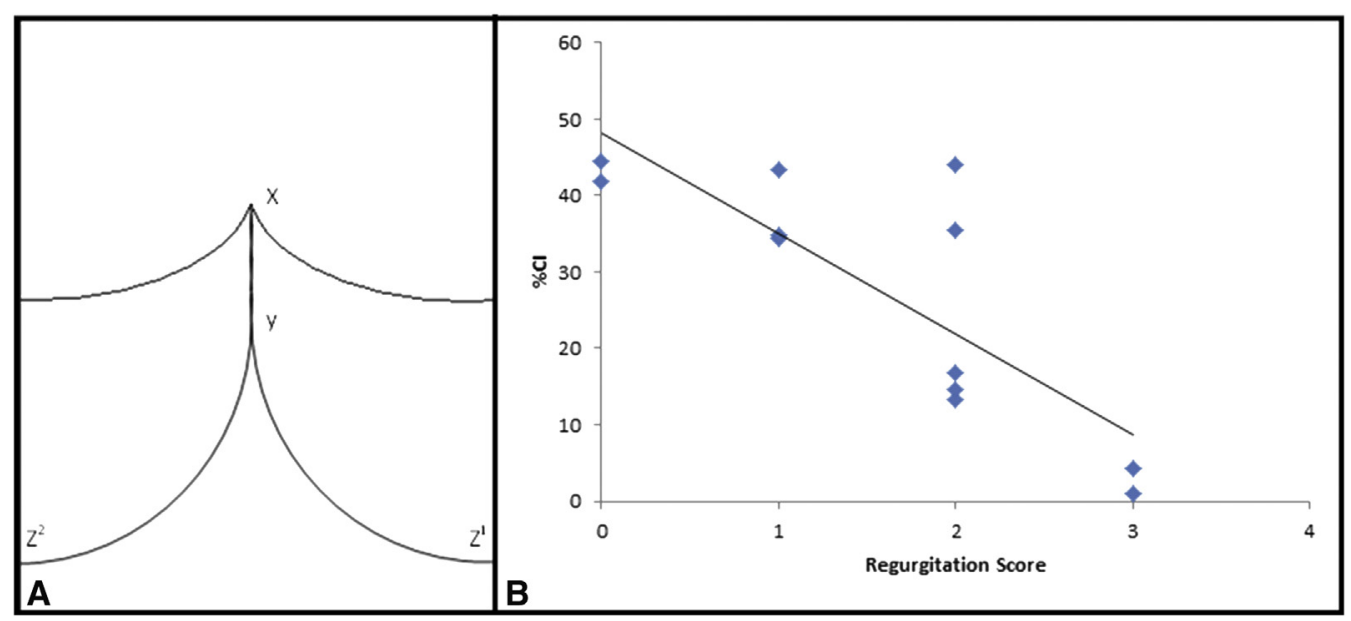

FIGURE 1. A, Schematic of the coaptation index ( $\%$ coaptation) measured in the long-axis view in diastole. Curvilinear distance: $x-y=$ coaptation length; $x-z=$ radial length of the diastolically loaded semilunar leaflet. Lune meridians lengths are proportional to surface areas; thus, $\left(\frac{x-y}{x-z}\right) \times 100=\%$ coaptation area. B, Scatterplot of regurgitation scores ( $x$-axis) and \% coaptation ( $y$-axis). As regurgitation severity score increased, the $\%$ coaptation decreased.

function, and valve dimensions were assessed by both TEE and cardiac catheterization/angiography. After imaging, the animals were euthanized for explant pathology.

\section{Cusp Apposition and Valve Competence}

By 2-dimensional TEE, cusp apposition was measured quantitatively using a leaflet coaptation index (\% coaptation; Figure 1, A). Because semilunar leaflets are by definition portions of geometric spherical lunes, the area of cuspal appositional contact is directly proportional to the curvilinear radial length of the contact as a ratio to the arc length of the entire lune along the same meridian normal to the great circle defining the lune. Thus, the proportional cuspal area of apposition (\%) can be measured in diastole with a 2-dimensional long-axis TEE view using the cursor function. This is independent of the absolute cuspal areal dimensions, calculated as the maximum curvilinear distance of leaflet coaptation during diastole divided by the leaflet radial dimension (edge to base) multiplied by 100 (units, \% coaptation).

\section{Explant Pathology}

Explanted valves were photographed (CyberShot; Sony, Tokyo, Japan) and underwent gross, macroscopic (SteREO Discovery V12, Carl Zeiss, Oberkochen, Germany), and radiographic (Faxitron Bioptics, Tucson, Ariz) examination for calcifications. Longitudinal sections were cut through each cusp from free edge to base, including the corresponding sinus and arterial wall (Figure E2). Formalin-fixed, paraffin-embedded sections were used for hematoxylin and eosin (H\&E) staining, Movat pentachrome staining, and immunohistochemistry. Primary antibodies included $\alpha$-smooth muscle actin ( $\alpha$-SMA; Dako, Carpinteria, Calif), von Willebrand factor (vWF; Dako), heat-shock protein 47 (HSP-47; Enzo Life Sciences, Farmingdale, NY), vimentin (Abcam, San Francisco, Calif) and proliferating cell nuclear antigen (PCNA; Abcam). Secondary antibodies were biotinylated fluorescein-conjugated or Texas red-conjugated, and nuclei were counterstained with 4',6-diamidino-2-phenylindole (Vector Laboratories, Burlingame, Calif). Slides were examined via fluorescence microscopy and imaging software (Axio Imager Z1 with ApoTome; AxioVision; Carl Zeiss). The density, distribution, and phenotypes of autologous valve interstitial cells (VICs) and valve endothelial cells (VECs) in the valve cusps, sinus walls, and PA were evaluated. A pattern of $\alpha-\mathrm{SMA}^{+}$, vimentin ${ }^{+}$, $\mathrm{HSP}-47^{+}$and $\mathrm{vWF}^{-}$expression was considered consistent with a VIC phenotype, whereas surface localization combined with $\mathrm{vWF}^{+}$was considered consistent with a VEC phenotype. ${ }^{21-23}$

To calculate cell density, $2 \mathrm{H \& E}$-stained slides per cusp were prepared, 1 slide from the left half of each cusp and 1 slide from the right half of each cusp. Quantified regions included the entire cusp (divided into one-third length sections: base, mid, and distal), the area below the wall attachment of the base of the cusp (sub-base; defined by a position abluminal to the mid-tangent of a line connecting the outflow and inflow cusp-wall junctions), the sinus of Valsalva, and the conduit distal to the sinotubular junction (Figure E2). Counted cells were categorized by cell type and location using $100 \times$ H\&E-stained images normalized per $\mu \mathrm{m}^{2}$ (AxioVision).

\section{Data Management and Statistics}

Statistical analyses were performed using SPSS version 17 (SPSS, Chicago, Ill). The cell count data were normally distributed by the Kolmogrov-Smirnov test, so these quantitative variables were analyzed by 1-way ANOVA with the Tukey post hoc test. All other datasets were nonnormally distributed, so continuous and ordinal variables for these 3 groups were analyzed by the Kruskal-Wallis test with post hoc comparisons using Mann-Whitney $U$ and Dunn-Bonferroni tests. Paired data were analyzed by the Wilcoxon signed-rank test. Tabulated data are presented as median and interqurtile range with accompanying means and standard errors for all datasets. Qualitative variables were assessed by Pearson $\chi^{2}$ analysis. Correlations between variables were assessed via the Spearman correlation statistic. Statistical significance was set at $P<.05$.

\section{RESULTS}

During the implant-to-explant interval, similar enlargements were seen in native and both types of replacement valves in the internal geometric subvalvular RVOT, PV annulus diameters, effective orifice area (EOA), body weight, and body surface area (BSA) (Tables 1 and 2). Within treatments, increases reached statistical significance only in the BEPV group. EOA indexed to BSA did not change $(P=.569)$ over the 6-month period in either test valve group. Dobutamine infusion $(2 \mu \mathrm{g} / \mathrm{kg} / \mathrm{min})$ during stress TEE significantly increased 
TABLE 1. Individual valve measurements and implant and explant

\begin{tabular}{|c|c|c|c|c|c|c|c|c|c|}
\hline Treatment & $\begin{array}{l}\text { Time } \\
\text { point }\end{array}$ & Animal & $\begin{array}{c}\text { Body } \\
\text { weight, } \mathrm{kg}\end{array}$ & $\begin{array}{l}\text { Body surface } \\
\text { area, } \mathbf{m}^{2}\end{array}$ & $\begin{array}{l}\text { PA internal } \\
\text { diameter, cm }\end{array}$ & $\begin{array}{l}\text { RVOT internal } \\
\text { diameter, cm }\end{array}$ & $\begin{array}{l}\text { PV internal annulus } \\
\text { diameter, cm }\end{array}$ & $\begin{array}{c}\text { PV effective } \\
\text { orifice area, } \mathbf{c m}^{2}\end{array}$ & $\begin{array}{c}\text { PV indexed } \\
\text { EOA }, \mathrm{cm}^{2} / \mathrm{m}^{2}\end{array}$ \\
\hline \multirow[t]{6}{*}{ CryoV } & \multirow[t]{3}{*}{ Implant } & Valve 1 & 19.1 & 0.66 & 1.21 & 1.60 & 1.43 & 1.28 & 1.94 \\
\hline & & Valve 2 & 16.4 & 0.60 & 1.29 & 1.70 & 1.66 & 1.87 & 3.12 \\
\hline & & Valve 3 & 19.5 & 0.67 & 1.20 & 1.70 & 1.82 & 1.63 & 2.43 \\
\hline & \multirow[t]{3}{*}{ Explant } & Valve 1 & 49.1 & 1.16 & 1.81 & 2.06 & 1.95 & 2.46 & 2.12 \\
\hline & & Valve 2 & 35.0 & 0.97 & 1.83 & 2.00 & 2.07 & 2.76 & 2.85 \\
\hline & & Valve 3 & 30.5 & 0.88 & 1.73 & 1.97 & 1.92 & 2.63 & 2.99 \\
\hline \multirow[t]{14}{*}{ BEPV } & \multirow[t]{7}{*}{ Implant } & Valve 4 & 19.1 & 0.66 & 1.34 & 1.70 & 1.61 & 1.56 & 2.36 \\
\hline & & Valve 5 & 20.5 & 0.69 & 1.33 & 1.67 & 1.65 & 1.91 & 2.77 \\
\hline & & Valve 6 & 20.9 & 0.70 & 1.36 & 1.86 & 1.82 & 2.48 & 3.54 \\
\hline & & Valve 7 & 20.0 & 0.68 & 1.19 & 1.84 & 1.75 & 2.05 & 3.02 \\
\hline & & Valve 8 & 19.1 & 0.66 & 1.36 & 1.78 & 1.58 & 1.76 & 2.67 \\
\hline & & Valve 9 & 20.0 & 0.69 & 1.36 & 1.90 & 1.62 & 1.94 & 2.81 \\
\hline & & Valve 10 & 21.8 & 0.71 & 1.45 & 1.65 & 1.54 & 1.69 & 2.38 \\
\hline & \multirow[t]{7}{*}{ Explant } & Valve 4 & 35.5 & 0.95 & 1.78 & 2.00 & 1.78 & 2.46 & 2.59 \\
\hline & & Valve 5 & 43.2 & 1.09 & 1.90 & 2.01 & 1.90 & 2.77 & 2.54 \\
\hline & & Valve 6 & 40.5 & 1.04 & 1.84 & 2.13 & 2.06 & 3.10 & 2.98 \\
\hline & & Valve 7 & 55.5 & 1.27 & 1.60 & 1.94 & 1.86 & 2.68 & 2.11 \\
\hline & & Valve 8 & 33.6 & 0.96 & 1.60 & 1.84 & 1.79 & 2.46 & 2.56 \\
\hline & & Valve 9 & 38.2 & 1.03 & 1.47 & 1.97 & 1.85 & 2.67 & 2.59 \\
\hline & & Valve 10 & 32.7 & 0.93 & 1.58 & 1.99 & 1.94 & 2.88 & 3.10 \\
\hline \multirow[t]{3}{*}{ Native } & \multirow[t]{3}{*}{ Explant } & Valve 11 & 35.5 & 0.97 & 2.03 & 2.11 & 1.78 & 2.89 & 2.98 \\
\hline & & Valve 12 & 36.8 & 1.00 & 1.90 & 2.02 & 1.88 & 2.84 & 2.84 \\
\hline & & Valve 13 & 36.4 & 1.00 & 2.14 & 2.16 & 2.02 & 3.36 & 3.36 \\
\hline
\end{tabular}

$P A$, Pulmonary artery; $R V O T$, right ventricular outflow tract; $P V$, pulmonary valve; $E O A$, effective orifice area; $C r y o V$, cryopreserved pulmonary valve; $B E P V$, bioengineered pulmonary valve.

cardiac output $(P=.05)$, but gradients remained low (physiological) even at the highest outputs. Within treatments, increases in cardiac output and peak and mean gradient reached statistical significance only in the BEPV group (Table E1). Angiographic measurements were confirmatory of TEE assessments of regurgitation and dimensions (data not shown).

\section{Semilunar Valve Function}

The effective cusp appositional mechanism as quantitated by $\%$ coaptation was correlated with the corresponding regurgitation scores $(r=-0.611, P=.026$ ) (Figure $1, B$ and Table E2). All native valves had $\%$ coaptation $>40 \%$ and zero to trace regurgitation (Table 3). Two CryoVs scored $2+$ (mild) regurgitation but had $\%$ coaptation $<15 \%$ $(13.20 \%$ and $14.62 \%)$. The third and most dysfunctional CryoV had $3+$ (moderate) regurgitation with a $\%$ coaptation of $0.94 \%$. Six of the 7 BEPVs had trace $(\mathrm{n}=3)$ to mild $(\mathrm{n}=3)$ regurgitation; $\%$ coaptation was $>34 \%$ in 4 of these, $16.8 \%$ (mild regurgitation) in 1 , and $25.2 \%$ (trace regurgitation) in 1 . The $1 \mathrm{BEPV}$ with moderate regurgitation had a $\%$ coaptation of $4.3 \%$. The general correlation of more regurgitation with smaller coaptation area is depicted in Figure 1, $B$. The 3 valve types were dissimilar by area of coaptation as a percentage of leaflet surface $(P=.047)$; post hoc tests comparing specific groups indicated that
BEHVs were similar to native $(P=.12)$, but CryoVs were significantly less so $(P=.043)$. CryoV leaflets were thicker than native leaflets $(P=.040)$ but similar to BEPV leaflets $(P=.429)$. In addition, the conduit wall thickness of CryoVs was similar to native $(P=.793)$, but thicker than BEPVs $(P=.01)$ Mean leaflet and wall thicknesses were $0.90 \pm 0.15 \mathrm{~mm}$ and $2.77 \pm 0.15 \mathrm{~mm}$, respectively, in CryoVs and $0.60 \pm 0.30 \mathrm{~mm}$ and $1.46 \pm 0.15 \mathrm{~mm}$, respectively, in BEPVs. Results of correlation analyses are presented in Table E2.

\section{Explant Pathology, Histology, Quantitative} Morphometry, and Immunohistochemistry

None of the explanted BEPVs showed evidence of mineralization by specimen $\mathrm{x}$-ray or histology, although mild calcifications were observed at the suture lines. Cusps were mobile in all test valves. One CryoV had a calcified nodule on a cusp and early calcified sinus wall plaques. CryoVs and BEPVs had distinctly different cell population patterns (Figure 2). Restoration of VECs was more extensive on the outflow surface of the mid-cusp regions of BEPVs compared with CryoVs (Table 4). VECs at the cusp base were similar in the 3 groups. VIC restoration in the sinus and PA wall of BEPVs was similar to that of natives $(P=.76 ; P=.73)$ and greater than that of CryoVs $(P<.001 ; P=.047)$ (Figure 3 and Table 5). Compared with 
TABLE 2. Somatic growth and TEE valve dimensional parameters by valve type

\begin{tabular}{|c|c|c|c|c|c|}
\hline \multirow[b]{3}{*}{ Variable } & \multicolumn{5}{|c|}{ CryoV $(n=3)$} \\
\hline & \multicolumn{2}{|c|}{ Implant } & \multicolumn{2}{|c|}{ Explant } & \multirow[b]{2}{*}{$P$ value } \\
\hline & $\begin{array}{l}\text { Median ( } 25 \%-75 \% \\
\text { interquartile range) }\end{array}$ & Mean (SEM) & $\begin{array}{l}\text { Median ( } 25 \%-75 \% \\
\text { interquartile range) }\end{array}$ & Mean (SEM) & \\
\hline Body weight, $\mathrm{kg}$ & $19.10(17.75-19.20)$ & $18.33(0.97)$ & $35.00(32.75-42.05)$ & $38.20(5.60)$ & .109 \\
\hline Body surface area, $\mathrm{m}^{2}$ & $0.66(0.63-0.66)$ & $0.64(0.02)$ & $0.97(0.93-1.07)$ & $1.00(0.08)$ & .109 \\
\hline PA internal diameter, $\mathrm{cm}$ & $1.21(1.21-1.23)$ & $1.23(0.03)$ & $1.81(1.77-1.82)$ & $1.79(0.03)$ & .109 \\
\hline RVOT internal diameter, $\mathrm{cm}$ & $1.70(1.65-1.70)$ & $1.67(0.03)$ & $2.00(1.99-2.03)$ & $2.01(0.03)$ & .109 \\
\hline PV internal annulus diameter, $\mathrm{cm}$ & $1.66(1.55-1.70)$ & $1.64(0.11)$ & $1.95(1.94-2.01)$ & $1.98(0.05)$ & .109 \\
\hline PV effective orifice area, $\mathrm{cm}^{2}$ & $1.63(1.46-1.69)$ & $1.59(0.17)$ & $2.63(2.55-2.70)$ & $2.62(0.09)$ & .109 \\
\hline $\mathrm{PV}$ indexed EOA, $\mathrm{cm}^{2} / \mathrm{m}^{2}$ & $2.43(2.19-2.60)$ & $2.50(0.34)$ & $2.85(2.48-2.92)$ & $2.65(0.27)$ & .593 \\
\hline
\end{tabular}

TEE, Transesophageal echocardiography; CryoV, cryopreserved pulmonary valve; $B E P V$, bioengineered pulmonary valve; $S E M$, standard error of the mean; $P A$, pulmonary artery; RVOT, right ventricular outflow tract; $P V$, pulmonary valve; $E O A$, effective orifice area.

natives, CryoVs were hypocellular in the sinus $(P=.017)$ and PA walls $(P=.03)$. BEPV VICs showed a typical myofibroblast phenotype $\left(\alpha-\mathrm{SMA}^{+}\right.$, vimentin ${ }^{+}$, HSP$47^{+}$). BEPVs had more VICs in the cusp base than CryoVs but fewer than natives, and normal densities in the sub-base region (ie, in the sinus wall/annulus region supporting cusp attachment). All implanted valves demonstrated variable sheathing (pannus) emanating from suture lines with variable extension along abluminal and luminal surfaces, occasionally extending to proximal leaflet-wall junction with no cusp tethering (Figures E3 and E4). No chronic inflammatory infiltrates were seen except in surrounding sutures.

\section{DISCUSSION}

To maintain stable hemodynamics and valve competence during diastole, as BSA and cardiac output increase, native heart structures enlarge in concert (ie, synchronous allometric and somatic growth). The 4 components of the semilunar valve complex (annulus, sinus walls, cusps, and PA) must enlarge in longitudinal, radial, and circumferential dimensions and remain compliant to maintain competence. ${ }^{24,25}$ As a native valve annulus increases in diameter during organ growth, the surface area of each cusp must enlarge in both radial and circumferential dimensions to maintain stable areas of leaflet coaptation. In a native valve, this requires a VIC population that is actively synthesizing structural proteins. Our group has previously demonstrated in both juvenile sheep and young adult baboons that decellularized and conditioned (bioengineered) pulmonary valves reendothelialize and completely recellularize the vascular walls with VICs but sparsely reestablish matrix cell populations in the cusps, with more cells repopulating proximally near the cusp origin from the sinus wall and partially extending into the nonappositional portion of the proximal cusps (base). ${ }^{12,13,15}$ This is now confirmed to occur similarly in young lambs.

TABLE 3. Individual valve measurements of cusp function at explant

\begin{tabular}{|c|c|c|c|c|c|c|c|c|c|c|c|c|}
\hline \multirow[b]{3}{*}{ Treatment } & \multirow[b]{3}{*}{ Animal } & \multicolumn{5}{|c|}{ Individual valve cusp function } & \multicolumn{6}{|c|}{ Treatment group cusp function comparisons } \\
\hline & & \multirow[b]{2}{*}{$\begin{array}{c}\text { Coaptation } \\
\text { index, } \%\end{array}$} & \multirow[b]{2}{*}{$\begin{array}{c}\text { Leaflet } \\
\text { thickness, } \\
\text { cm }\end{array}$} & \multirow[b]{2}{*}{$\begin{array}{c}\text { Conduit } \\
\text { wall } \\
\text { thickness, } \\
\text { cm } \\
\end{array}$} & \multirow[b]{2}{*}{$\begin{array}{c}\text { Mean } \\
\text { gradient, } \\
\text { mm Hg }\end{array}$} & \multirow[b]{2}{*}{$\begin{array}{l}\text { Regurgitation } \\
\text { score }\end{array}$} & \multicolumn{2}{|c|}{ Coaptation index } & \multicolumn{2}{|c|}{ Leaflet thickness } & \multicolumn{2}{|c|}{ Conduit wall thickness } \\
\hline & & & & & & & $\begin{array}{c}\text { Median } \\
(25 \%-75 \% \\
\text { interquartile } \\
\text { range) }\end{array}$ & $\begin{array}{l}\text { Mean } \\
\text { (SEM) }\end{array}$ & $\begin{array}{c}\text { Median } \\
(25 \%-75 \% \\
\text { interquartile } \\
\text { range })\end{array}$ & $\begin{array}{l}\text { Mean } \\
\text { (SEM) }\end{array}$ & $\begin{array}{c}\text { Median } \\
(25 \%-75 \% \\
\text { interquartile } \\
\text { range) }\end{array}$ & $\begin{array}{l}\text { Mean } \\
\text { (SEM) }\end{array}$ \\
\hline \multirow[t]{3}{*}{ CryoV } & Valve 1 & 13.2 & 0.7 & 2.5 & 2 & Mild (2+) & $13.20^{\mathrm{a}}(7.07-13.91)$ & $9.59(4.34)$ & $0.80^{\mathrm{a}}(.75-1.00)$ & $0.90(0.15)$ & $2.80^{\mathrm{a}}(2.65-2.90)$ & $2.77(0.15)$ \\
\hline & Valve 2 & 14.62 & 0.8 & 2.8 & 2 & Mild (2+) & & & & & & \\
\hline & Valve 3 & 0.94 & 1.2 & 3.0 & 2 & Moderate $(3+)$ & & & & & & \\
\hline \multirow[t]{7}{*}{ BEPV } & Valve 4 & 4.3 & 0.6 & 1.1 & 1 & Moderate $(3+)$ & $34.29^{\mathrm{a}, \mathrm{b}}(21.00-35.13)$ & $27.85(5.11)$ & $0.65^{\mathrm{a}, \mathrm{b}}(0.60-0.75)$ & $0.66(0.04)$ & $1.30^{\mathrm{b}}(1.15-1.80)$ & $1.46(0.15)$ \\
\hline & Valve 5 & 16.8 & 0.5 & 1.0 & 1 & Mild (2+) & & & & & & \\
\hline & Valve 6 & 25.2 & 0.6 & 1.7 & 1 & Trace (1+) & & & & & & \\
\hline & Valve 7 & 34.29 & 0.8 & 1.2 & 1 & Trace $(1+)$ & & & & & & \\
\hline & Valve 8 & 34.8 & 0.8 & 2.0 & 2 & Trace (1+) & & & & & & \\
\hline & Valve 9 & 35.45 & 0.6 & 1.9 & 1 & Mild (2+) & & & & & & \\
\hline & Valve 10 & 44.1 & 0.7 & 1.3 & 2 & Mild (2+) & & & & & & \\
\hline \multirow[t]{3}{*}{ Native } & Valve 11 & 43.43 & 0.5 & 2.0 & 2 & Mild (2+) & $43.43^{\mathrm{b}}(43.59-44.00)$ & $43.25(0.82)$ & $0.50^{\mathrm{b}}(0.05-0.55)$ & $0.53(0.03)$ & $2.00^{\mathrm{a}, \mathrm{b}}(2.00-2.00)$ & $2.00(0.00)$ \\
\hline & Valve 12 & 44.58 & 0.5 & 2.0 & 1 & None (0) & & & & & & \\
\hline & Valve 13 & 41.75 & 0.6 & 2.0 & 1 & Trace $(1+)$ & & & & & & \\
\hline
\end{tabular}

$\overline{S E M}$, Standard error of the mean; $C r y o V$, cryopreserved pulmonary valve; $B E P V$, bioengineered pulmonary valve. ${ }^{\mathrm{a}, \mathrm{b}}$ Groups with the same superscript are not significantly different at $P \leq .05$. 
TABLE 2. Continued

\begin{tabular}{|c|c|c|c|c|c|c|c|}
\hline \multicolumn{5}{|c|}{$\operatorname{BEPV}(n=7)$} & \multicolumn{2}{|c|}{ Native $(\mathbf{n}=3)$} & \multirow{2}{*}{$\begin{array}{c}\text { Implant } \\
\text { vs explant }\end{array}$} \\
\hline Implar & & Expla & & & Expla & & \\
\hline $\begin{array}{l}\text { Median (25\%-75\% } \\
\text { interquartile range) }\end{array}$ & Mean (SEM) & $\begin{array}{l}\text { Median ( } 25 \%-75 \% \\
\text { interquartile range) }\end{array}$ & Mean (SEM) & $P$ value & $\begin{array}{l}\text { Median (25\%-75\% } \\
\text { interquartile range) }\end{array}$ & Mean (SEM) & $P$ value \\
\hline $20.00(19.55-20.70)$ & $20.20(0.37)$ & $38.20(34.55-41.85)$ & $39.89(2.96)$ & .018 & $36.40(35.95-36.60)$ & $36.23(0.384)$ & .909 \\
\hline $0.69(0.67-0.70)$ & $0.68(0.01)$ & $1.03(0.96-1.07)$ & $1.04(0.04)$ & .018 & $1.00(0.99-1.00)$ & $0.99(0.01)$ & .909 \\
\hline $1.35(1.34-1.60)$ & $1.34(0.03)$ & $1.60(1.59-1.81)$ & $1.68(0.06)$ & .018 & $2.03(1.97-2.09)$ & $2.02(0.07)$ & .053 \\
\hline $1.74(1.69-1.85)$ & $1.77(0.04)$ & $1.99(1.96-2.01)$ & $1.98(0.03)$ & .018 & $2.11(2.07-2.14)$ & $2.10(0.04)$ & .301 \\
\hline $1.62(1.60-1.70)$ & $1.65(0.04)$ & $1.86(1.82-1.92)$ & $1.88(0.04)$ & .018 & $1.88(1.83-1.95)$ & $1.89(0.07)$ & .425 \\
\hline $1.84(1.73-2.00)$ & $1.91(0.11)$ & $2.68(2.57-2.83)$ & $2.72(0.09)$ & .018 & $2.89(2.87-3.13)$ & $3.03(0.17)$ & .138 \\
\hline $2.72(2.52-2.91)$ & $2.79(0.15)$ & $2.59(2.55-2.79)$ & $2.64(0.12)$ & .398 & $2.98(2.91-3.17)$ & $3.06(0.16)$ & .569 \\
\hline
\end{tabular}

The reduced cusp coaptation areas in CryoV recapitulate the clinical experience with homograft valves that fail with fibrosis, retraction, and calcification causing regurgitation and/or stenosis. ${ }^{26,27}$ In this study, the coaptation index was correlated with the regurgitation scores and thus may be an attractive nondestructive in vivo quantitative measurement for comparing cusp closure mechanics. A number of valve functional measurement differences did not reach statistical significance, given the intrinsic study limitation of small numbers in the CryoV and native groups driven by an experimental design using only recipient animals from a single flock to limit breed and animal variations in the size and rates of somatic growth. For example, the ordinal regurgitation score for BEPVs averaged 1.7 (between trace and mild), whereas those for CryoVs averaged 2.3 (between mild and moderate).

Because leaflet VIC recellularization did not occur in the majority of the BEPVs beyond the flexion region at

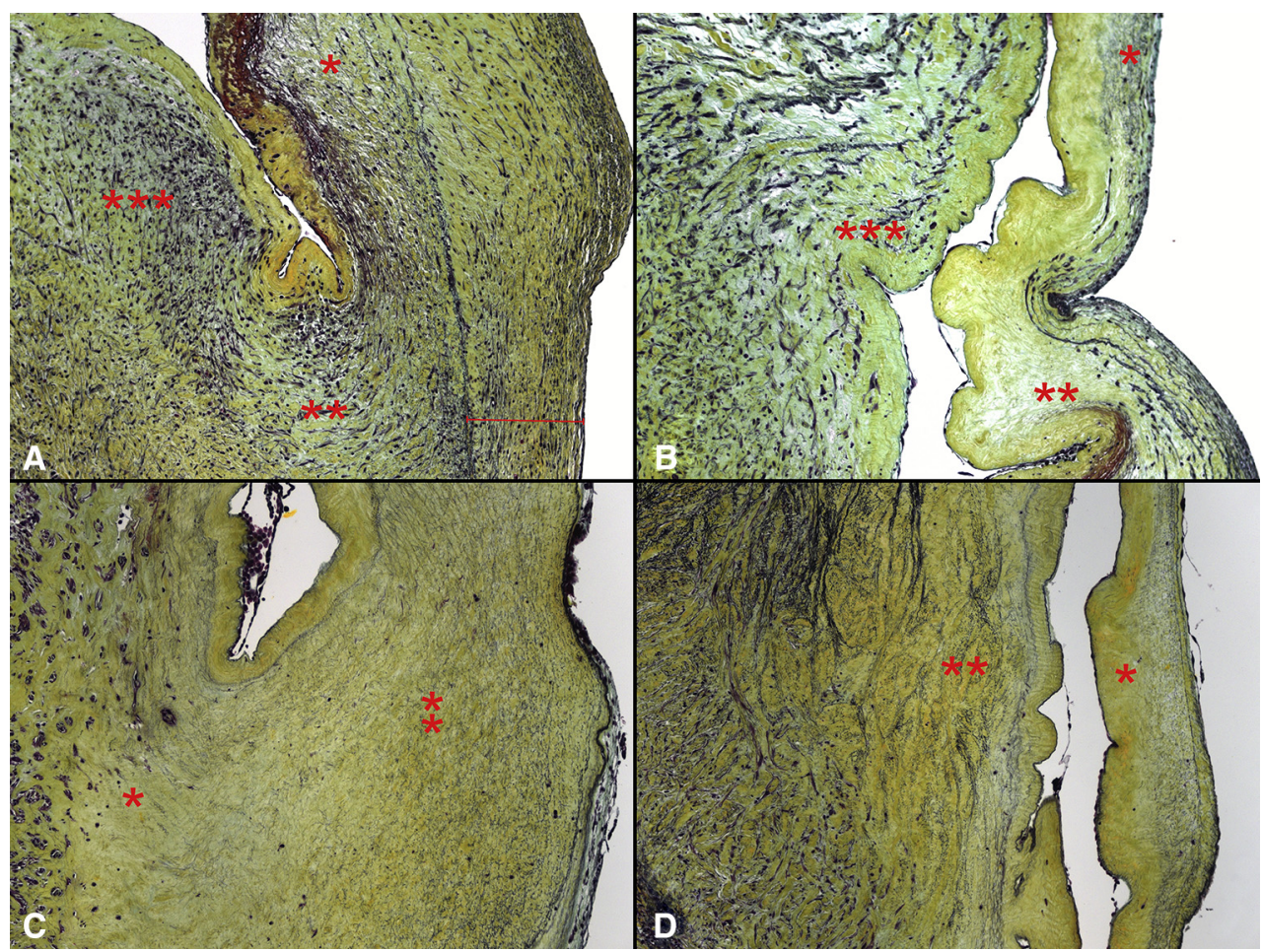

FIGURE 2. Representative images depicting recellularization of cusp base and sub-base regions of BEPVS (A and B) compared with CryoVs (C and D) at explant (all Movat pentachrome, 100×). In the BEPVs, in-migrating cells from the sinus (A, ***) and sub-base regions (A, **) extend into the cusp base $(\mathrm{A}, *)$ and fibrous sheath (A, line). Note, in A, that leaflet folded back on itself. Recellularization of the proximal cusp is apparent but incomplete (B, **). Cusp re-endothelialization $(\mathrm{B}, *)$ and transmural recellularization of the PA wall $(\mathrm{B}, * * *)$ are common. CryoVs demonstrate hypocellularity in the sub-base region $(\mathrm{C}, *)$ and cusp base $(\mathrm{C}, * *)$, as well as incomplete transmural PA cell retention $(\mathrm{D}, * *)$ and virtually acellular cusp matrix $(\mathrm{D}, *)$. 
TABLE 4. Quantitative morphometric measurement of regional cell densities for valve endothelial cells in explanted cusps

\begin{tabular}{|c|c|c|c|c|c|c|c|c|c|c|c|c|c|}
\hline \multirow[b]{3}{*}{ Treatment } & \multirow[b]{3}{*}{$\mathbf{n}$} & \multicolumn{4}{|c|}{ Base } & \multicolumn{4}{|c|}{ Mid } & \multicolumn{4}{|c|}{ Distal } \\
\hline & & \multicolumn{2}{|c|}{ oVECs, $\times 10^{-5}$} & \multicolumn{2}{|c|}{ iVECs, $\times 10^{-5}$} & \multicolumn{2}{|c|}{ oVECs, $\times 10^{-5}$} & \multicolumn{2}{|c|}{ iVECs, $\times 10^{-5}$} & \multicolumn{2}{|c|}{ oVECs, $\times 10^{-5}$} & \multicolumn{2}{|c|}{ iVECs, $\times 10^{-5}$} \\
\hline & & Mean & SEM & Mean & SEM & Mean & SEM & Mean & SEM & Mean & SEM & Mean & SEM \\
\hline CryoV & 3 & 11.54 & 2.97 & 6.48 & 1.91 & 15.74 & 2.49 & 10.60 & 1.98 & 17.29 & 3.83 & $9.87^{\mathrm{a}}$ & 2.25 \\
\hline BEPV & 7 & 6.19 & 0.94 & 7.99 & 1.26 & 15.69 & 3.25 & 17.47 & 2.40 & 30.46 & 4.88 & $22.92^{\mathrm{b}}$ & 3.33 \\
\hline Native & 3 & 10.23 & 1.24 & 6.01 & 0.87 & 15.44 & 1.26 & 9.09 & 0.66 & 23.37 & 2.11 & $16.93^{\mathrm{a}, \mathrm{b}}$ & 1.50 \\
\hline
\end{tabular}

$\overline{o V E C s}$, Outflow valve endothelial cells; $i V E C s$, inflow valve endothelial cells; SEM, standard error of the mean; $C r y o V$, cryopreserved pulmonary valve; $B E P V$, bioengineered pulmonary valve. ${ }^{\mathrm{a}, \mathrm{b}}$ Means with the same superscript are not significantly different at $P \leq .05$.

the cusp base, ECM remodeling in the "belly" portion of the leaflets during this period of robust lamb somatic growth could not explain the more extensive leaflet-toleaflet coaptation in the BEPVs as annulus and conduit geometric dimensions increased. The sub-base VIC cellularity of BEPVs was more similar to that of natives (Figures 2-4). Cell density averaged 3 times that of CryoVs, but only one-half that of natives. BEPVs are implanted as totally acellular constructs, so all viable cells were in-migrating (ie, in vivo recellularization). These cells were positive for HSP-47, a collagen chaperone protein, the presence of which indicates active collagen synthesis, consistent with known VIC phenotype and function. ${ }^{28-31}$ CryoVs are in the process of declining VIC cellularity (from normal to devoid of cells), whereas BEPVs are increasing in cellularity from zero (decellularized). Thus, the directional change in the 2 populations is distinctly different even if quantitatively similar at some point in time. Conceptually, if BEHVs are indeed undergoing autologous in vivo

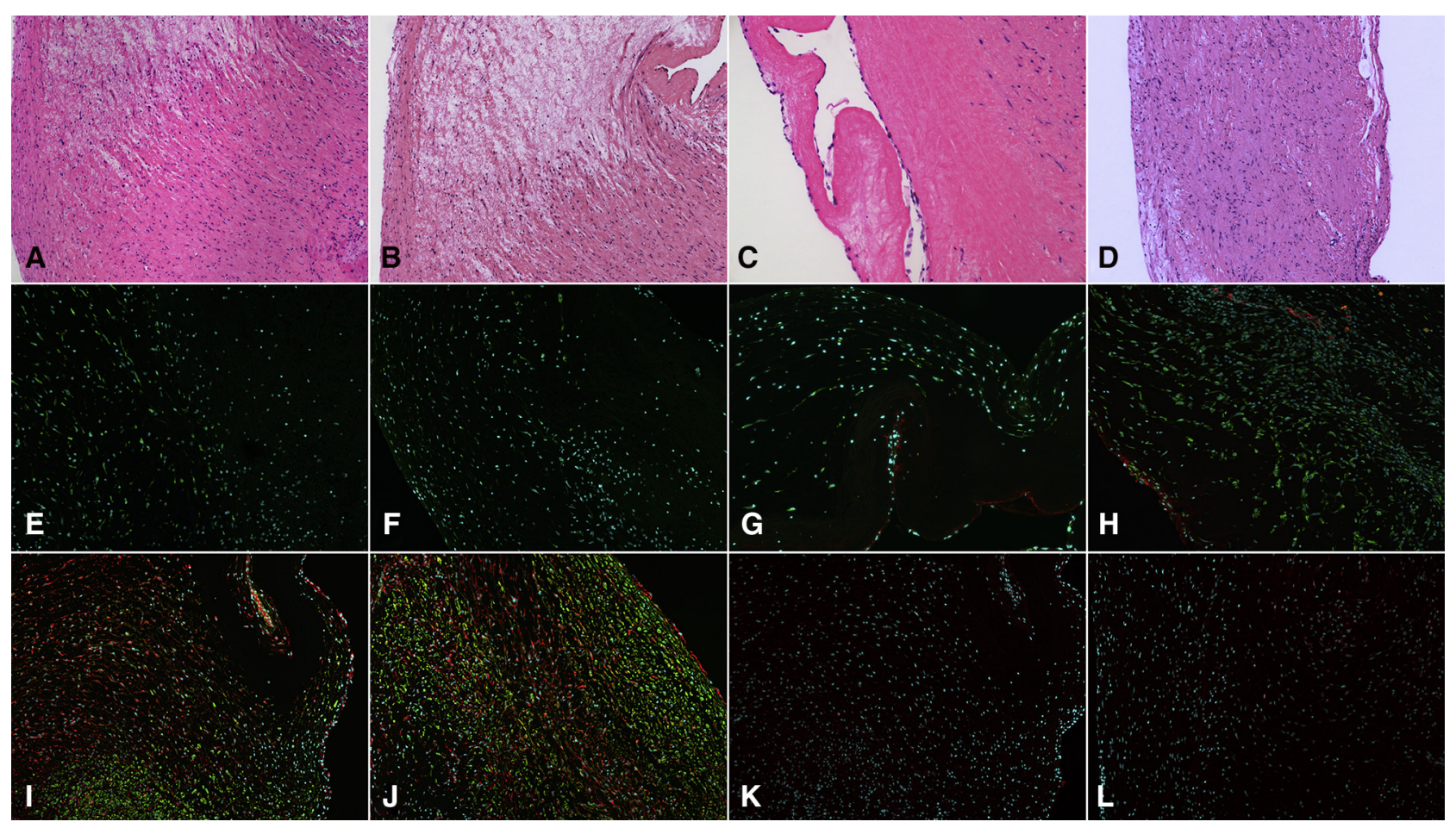

FIGURE 3. Histology and immunohistochemistry of BEPVs explanted after 6 months. Representative images from BEPVs depicting transmural recellularization of cusp base and sub-base regions as well as sinus and PA walls by cells consistent with the myofibroblast VIC phenotype. Positive $\alpha$-SMA staining suggests contractile and migratory functionality, whereas HSP- $47^{+}$suggests active collagen synthesis and $\mathrm{PCNA}^{+}$indicates proliferative capacity in the recellularized population. Mid to distal cusp portions have VEC restoration of blood-exposed surfaces but minimal VIC restoration. A-D, Histological sections (H\&E of the sub-base region (A), cusp base (B), distal cusp (C, magnification 200×), and distal conduit (D) demonstrating recellularization of the cusp base and conduit). E-H, HSP- $47^{+}$(green) cells at the base of the cusp (E), in the sub-base region (F), in the pannus at the mid-cusp $(\mathrm{G})$, and in the sinus $(\mathrm{H})$ and $\mathrm{vWF}^{+}$(red) cells within the pannus $(\mathrm{G})$ and in the sinus $(\mathrm{H})$. I and $\mathrm{J}, \alpha-\mathrm{SMA}^{+}$(green) cells and vimentin ${ }^{+}$(red) cells in the cusp sub-base (I) and base (J) regions. $\mathrm{K}$ and L, $\mathrm{PCNA}^{+}($red $)$cells in the cusp base $(\mathrm{K})$ and sub-base (L) regions. Nuclear DNA is demonstrated by $4^{\prime}, 6$-diamidino-2-phenylindole staining (blue); elastic fibers are autofluorescent. 
TABLE 5. Quantitative morphometric measurement of regional cell densities for valve interstitial cells in explanted valves

\begin{tabular}{|c|c|c|c|c|c|c|c|c|c|c|c|c|c|}
\hline \multirow[b]{3}{*}{ Treatment } & \multirow[b]{3}{*}{$\mathbf{n}$} & & & \multicolumn{6}{|c|}{ Cusp } & & & & \\
\hline & & \multicolumn{2}{|c|}{ Sub-base, $\times 10^{-5}$} & \multicolumn{2}{|c|}{ Base, $\times 10^{-5}$} & \multicolumn{2}{|c|}{ Mid, $\times 10^{-5}$} & \multicolumn{2}{|c|}{ Distal, $\times 10^{-5}$} & \multicolumn{2}{|c|}{ Sinus, $\times 10^{-5}$} & \multicolumn{2}{|c|}{$\mathbf{P A}, \times 10^{-5}$} \\
\hline & & Mean & SEM & Mean & SEM & Mean & SEM & Mean & SEM & Mean & SEM & Mean & SEM \\
\hline CryoV & 3 & 124.61 & 21.05 & 49.28 & 15.43 & 29.02 & 9.31 & 40.61 & 8.93 & $116.36^{\mathrm{a}}$ & 9.08 & $122.00^{\mathrm{a}}$ & 12.37 \\
\hline BEPV & 7 & 148.08 & 20.14 & 81.38 & 11.40 & 33.32 & 6.30 & 27.73 & 7.87 & $179.16^{\mathrm{b}}$ & 9.11 & $166.43^{\mathrm{b}}$ & 12.18 \\
\hline Native & 3 & 171.27 & 8.96 & $175.90^{\mathrm{a}}$ & 6.07 & $164.35^{\mathrm{a}}$ & 4.15 & $203.14^{\mathrm{a}}$ & 10.11 & $167.87^{\mathrm{b}}$ & 13.03 & $181.78^{\mathrm{b}}$ & 11.70 \\
\hline
\end{tabular}

$P A$, Pulmonary artery; $S E M$, standard error of the mean; $B E P V$, bioengineered pulmonary valve; $C r y o V$, cryopreserved pulmonary valve. ${ }^{\text {a,b }}$ Means with the same superscript letter are not significantly different at $P \leq .05$.

recellularization after surgery, there still must be an initial obligatory lag in recellularization and resumption of active matrix synthesis. Thus, it is possible that for clinical translation, application to neonates with the fastest rates of somatic growth may be best served by adding steps to accelerate cell homing or to formally tissue engineer the BEHVs by using preoperative ex vivo bioreactor cell seeding to "jump start" the cusp recell process. ${ }^{32}$ For older children in whom cardiac organ enlargement has slowed, this might not be necessary, and BEHVs could suffice initially as functional scaffolds and ultimately at least partially viable valves. ${ }^{33}$ The collagen-conditioned leaflets retained normal thicknesses to even slightly thinner than natives, quite different from the thickening of the classically cryopreserved valves. This could be related to increased tissue compliance, which could improve cusp closure dynamics by allowing greater radial

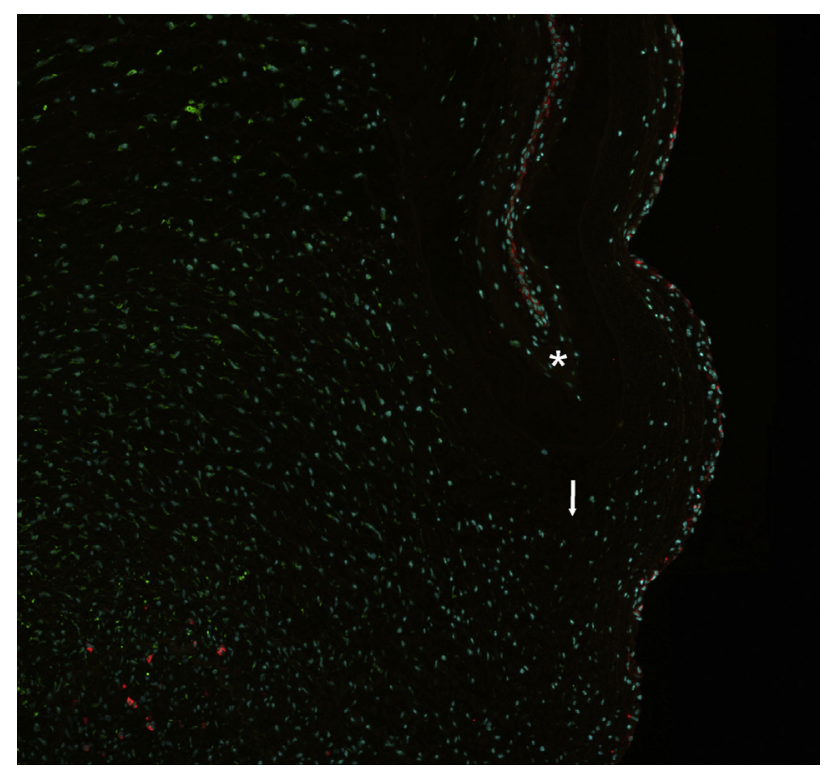

FIGURE 4. Immunohistochemistry of bioengineered heart valve leaflet base explanted at 6 months. Asterisk marks the upper left sinus wall junction. Arrow is the interstitial confluence of leaflet spongiosa with sinus wall. $B l u e=$ Dapi nuclear stain of viable cells recellularizing the initially acellular valve conduit. Green $=$ Heat-shock protein 47 , a valve interstitial cell marker. Red $=$ von Willebrand factor, a valve endothelial cell marker. Note that leaflet is in "open position abutting the sinus wall" $(100 \times)$. dimensional diastolic elongation as a passive mechanism for improving $\%$ coaptation indices independent or synergistic with ECM remodeling at the base. See Video 1 showing pulsatility of sinus and conduit walls.

Limitations of this study include the restricted numbers in the reference groups and the limited (6-month) duration of implantation, which preclude definitive mechanistic explanations for the favorable results. Our use of the sheep model limits protein antibody and commercially available gene primers and probes. Thus, further explorations with prolonged chronic implantation in baboons would be a logical next step, as this subhuman primate model would open up a full library of gene and protein expression targets for exploring the cell behavior and could better test prolonged durability of adaptations. Nonanatomic positioning of the valved conduit also could be tested in baboons. The steps for conditioning decellularized pulmonary valves are easily performed in the operating room (15-minute soaks) before implantation and are not significantly more challenging

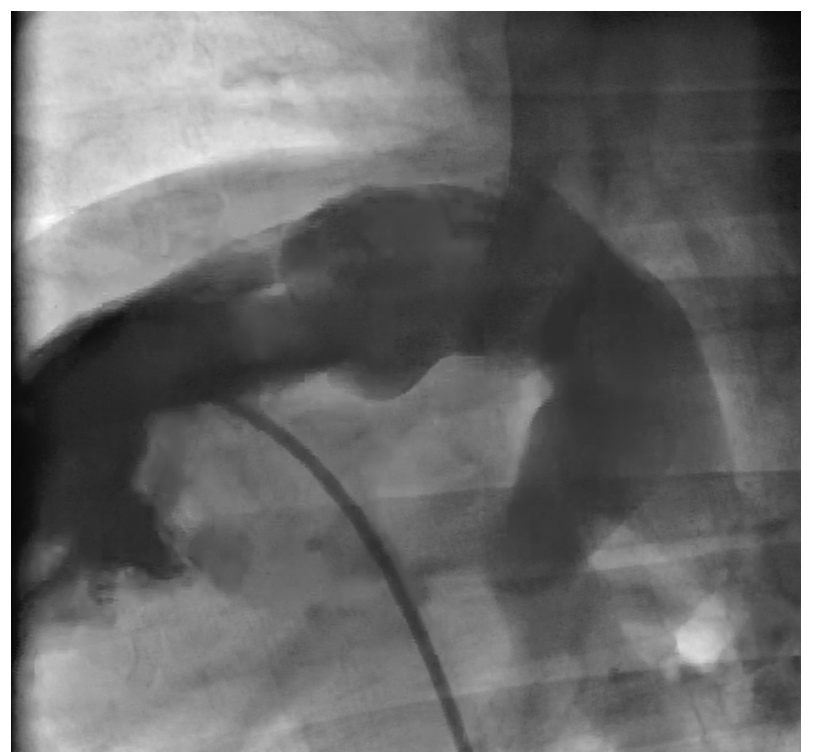

VIDEO 1. Video capture during TEE of the PV (long axis) in diastole, demonstrating the measurements taken to determine $\%$ coaptation and sinus and conduit wall retained compliance (pulsatility). Video available at http://www.jtcvsonline.org/article/S0022-5223(16)30489-5/addons. 
than the thawing procedures now routinely performed, so clinical transition is attractive.

Unlike the well-understood meaning of synchronous somatic and allometric growth during childhood with associated developmental and maturational elements, the term and conceptual definition of "growth" in an engineered biological valved conduit can be problematic. Often the term is used without rigor and in reference solely to increases in size, which can be a completely passive process in cardiovascular structures. For example, during the early days of homograft surgery, passive dilation was often inappropriately described as "growth," even though these tissues rapidly became acellular and the valves became regurgitant. ${ }^{18}$ In general, organism growth is defined as an increase in tissue mass due to absolute increases in cells, intracellular protoplasm, and associated extracellular proteins as part of developmental and maturational programs controlled at the molecular level. Thus, in the context of engineered heart valves, it may be preferable to describe changes in functional terms as ECM remodeling and avoid the term "growth." 34 Viable may be more appropriate to describe structures recellularized with phenotypically appropriate populations of metabolically active cells.

In summary, BEPVs as prepared here often retained better cusp coaptation in a rapidly growing weanling lamb model. Autologous recellularization of the matrix of sinus walls and cusp bases in decellularized BEPVs was consistently present and appeared to be of the VIC phenotype. Restored endothelium could normalize the blood-tissue interface. ${ }^{35}$ Better cusp function cannot be attributed to mid-cusp to distal cusp VIC recellularization, because this did not occur during the observed time frame. Bioengineering of allogeneic valves appears to promote at least partial early recellularization in vivo, with the potential of restoring some ECM remodeling capacity.

\section{Conflict of Interest Statement}

Children's Mercy Kansas City and the authors are named inventors on multiple patents involving bioengineered and tissue-engineered constructs. Authors have nothing to disclose with regard to commercial support.

The authors thank Ashley K. Sherman, MA, for providing statistical consultation.

\section{References}

1. Mery CM, Guzmán-Pruneda FA, De León LE, Zhang W, Terwelp MD, Bocchini CE, et al. Risk factors for development of endocarditis and reintervention in patients undergoing right ventricle to pulmonary artery valved conduit placement. J Thorac Cardiovasc Surg. 2016;151:432-41.e1-2.

2. Sacks MS, Schoen FJ, Mayer JE. Bioengineering challenges for heart valve tissue engineering. Annu Rev Biomed Eng. 2009;11:289-313.

3. Hilbert SL, Luna RE, Zhang J, Wang Y, Hopkins RA, Yu ZX, et al. Allograft heart valves: the role of apoptosis-mediated cell loss. J Thorac Cardiovasc Surg. 1999;117:454-62.
4. Brown JW, Ruzmetov M, Rodefeld MD, Turrentine MW. Right ventricular outflow tract reconstruction in Ross patients: does the homograft fare better? Ann Thorac Surg. 2008;86:1607-12.

5. Karamlou T, Blackstone EH, Hawkins JA, Jacobs ML, Kanter KR, Brown JW, et al. Can pulmonary conduit dysfunction and failure be reduced in infants and children less than age 2 years at initial implantation? J Thorac Cardiovasc Surg. 2006;132:829-38.

6. McKenzie ED, Khan MS, Dietzman TW, Guzmán-Pruneda FA, Samayoa AX, Liou A, et al. Surgical pulmonary valve replacement: a benchmark for outcomes comparisons. J Thorac Cardiovasc Surg. 2014;148:1450-3.

7. Fraser CD Jr. The ongoing quest for an ideal surgical repair for tetralogy of Fallot: focus on the pulmonary valve. J Thorac Cardiovasc Surg. 2015;149:1364.

8. Hibino N, McGillicuddy E, Matsumura G, Ichihara Y, Naito Y, Breuer C, et al. Late-term results of tissue-engineered vascular grafts in humans. J Thorac Cardiovasc Surg. 2010;139:431-6.e1-2.

9. Shin'oka T, Imai Y, Ikada Y. Transplantation of a tissue-engineered pulmonary artery. N Engl J Med. 2001;344:532-3.

10. Vesely I. Heart valve tissue engineering. Circ Res. 2005;97:743-55.

11. Dohmen PM, Lembcke A, Holinski S, Pruss A, Konertz W. Ten years of clinical results with a tissue-engineered pulmonary valve. Ann Thorac Surg. 2011;92:1308-14.

12. Quinn RW, Hilbert SL, Bert AA, Drake BW, Bustamante JA, Fenton JE, et al Performance and morphology of decellularized pulmonary valves implanted in juvenile sheep. Ann Thorac Surg. 2011;92:131-7.

13. Quinn RW, Hilbert SL, Converse GL, Bert AA, Buse E, Drake WB, et al. Enhanced autologous re-endothelialization of decellularized and extracellular matrix conditioned allografts implanted into the right ventricular outflow tracts of juvenile sheep. Cardiovasc Eng Technol. 2012;3:217-27.

14. Converse GL, Armstrong M, Quinn RW, Buse EE, Cromwell ML, Moriarty SJ, et al. Effects of cryopreservation, decellularization and novel extracellular matrix conditioning on the quasi-static and time-dependent properties of the pulmonary valve leaflet. Acta Biomater. 2012;8:2722-9.

15. Hopkins RA, Bert AA, Hilbert SL, Quinn RW, Brasky KM, Drake WB, et al. Bioengineered human and allogeneic pulmonary valve conduits chronically implanted orthotopically in baboons: hemodynamic performance and immunologic consequences. J Thorac Cardiovasc Surg. 2013;145:1098-107.

16. Hopkins RA. State of the art and science for clinical translation of regenerative cardiac surgery. Prog Pediatr Cardiol. 2013;35:79-85.

17. Hopkins RA, Lofland GK. Congenital, reconstructive and regenerative cardiac surgery. Prog Pediatr Cardiol. 2013;35:87-90.

18. Hopkins RA. Cardiac Reconstructions with Allograft Tissues. New York: Springer-Verlag; 2005.

19. Bert AA, Drake WB, Quinn RW, Brasky KM, O'Brien JE Jr, Lofland GK, et al. Transesophageal echocardiography in healthy young adult male baboons (Papio hamadryas anubis): normal cardiac anatomy and function in subhuman primates compared to humans. Prog Pediatr Cardiol. 2013;35:109-20.

20. Margossian R, Chen S, Sleeper LA, Tani LY, Shirali G, Golding F, et al. The reproducibility and absolute values of echocardiographic measurements of left ventricular size and function in children are algorithm dependent. J Am Soc Echocardiogr. 2015;28:549-58.e1.

21. De Visscher G, Plusquin R, Mesure L, Flameng W. Selection of an immunohistochemical panel for cardiovascular research in sheep. Appl Immunohistochem Mol Morphol. 2010;18:382-91.

22. Zaidi AH, Nathan M, Emani S, Baird C, del Nido PJ, Gauvreau K, et al. Preliminary experience with porcine intestinal submucosa (CorMatrix) for valve reconstruction in congenital heart disease: histologic evaluation of explanted valves. J Thorac Cardiovasc Surg. 2014;148:2216-25.e1.

23. Chester AH, Taylor PM. Molecular and functional characteristics of heart-valve interstitial cells. Philos Trans R Soc Lond B Biol Sci. 2007;362:1437-43.

24. Labrosse MR, Beller CJ, Boodhwani M, Hudson C, Sohmer B. Subject-specific finite-element modeling of normal aortic valve biomechanics from $3 \mathrm{D}+\mathrm{t}$ TEE images. Med Image Anal. 2015;20:162-72.

25. Stephens EH, Chu CK, Grande-Allen KJ. Valve proteoglycan content and glycosaminoglycan fine structure are unique to microstructure, mechanical load and age: relevance to an age-specific tissue-engineered heart valve. Acta Biomater. 2008;4:1148-60.

26. Bokma JP, Winter MM, Oosterhof T, Vliegen HW, van Dijk AP, Hazekamp MG, et al. Individualised prediction of pulmonary homograft durability in tetralogy of Fallot. Heart. 2015;101:1717-23.

27. Neumann A, Sarikouch S, Breymann T, Cebotari S, Boethig D, Horke A, et al. Early systemic cellular immune response in children and young adults receiving decellularized fresh allografts for pulmonary valve replacement. Tissue Eng Part A. 2014;20:1003-11. 
28. Iop L, Bonetti A, Naso F, Rizzo S, Cagnin S, Bianco R, et al. Decellularized allogeneic heart valves demonstrate self-regeneration potential after a long-term preclinical evaluation. PLoS One. 2014;9:e99593.

29. Huang W, Xiao DZ, Wang Y, Shan ZX, Liu XY, Lin QX, et al. Fn14 promotes differentiation of human mesenchymal stem cells into heart valvular interstitial cells by phenotypic characterization. J Cell Physiol. 2014;229:580-7.

30. Taylor PM, Allen SP, Yacoub MH. Phenotypic and functional characterization of interstitial cells from human heart valves, pericardium and skin. J Heart Valve Dis. 2000;9:150-8.

31. Rabkin-Aikawa E, Farber M, Aikawa M, Schoen FJ. Dynamic and reversible changes of interstitial cell phenotype during remodeling of cardiac valves. J Heart Valve Dis. 2004;13:841-7.

32. Converse GL, Buse EE, Neill KR, McFall CR, Lewis HN, VeDepo MC, et al. Design and efficacy of a single-use bioreactor for heart valve tissue engineering. J Biomed Mater Res B Appl Biomater. 2015 [Epub ahead of print].

33. Webber MJ, Khan OF, Sydlik SA, Tang BC, Langer R. A perspective on the clinical translation of scaffolds for tissue engineering. Ann Biomed Eng. 2015 43:641-56.

34. Ambrosi D, Ateshian GA, Arruda EM, Cowin SC, Dumais J, Goriely A, et al Perspectives on biological growth and remodeling. J Mech Phys Solids. 2011; 59:863-83.

35. Mongkoldhumrongkul N, Yacoub MH, Chester AH. Valve endothelial cells: not just any old endothelial cells. Curr Vasc Pharmacol. 2016;14:146-54.

Key Words: cardiac valves, cardiac valve prosthesis, pulmonary valve, bioengineering, tissue engineering, allografts

\section{EDITORIAL COMMENTARY}

\section{Making progress toward a tissue engineered heart valve}

John E. Mayer, Jr, MD

From the Department of Cardiac Surgery, Boston Children's Hospital, Boston, Mass.

Disclosures: Author has nothing to disclose with regard to commercial support.

Received for publication June 26, 2016; accepted for publication June 27, 2016; available ahead of print Aug 11, 2016.

Address for reprints: John E. Mayer, Jr, MD, Department of Cardiac Surgery, Boston Children's Hospital-Bader 273, 300 Longwood Ave, Boston, MA 02115 (E-mail: John.Mayer@cardio.chboston.org).

J Thorac Cardiovasc Surg 2016;152:1165-6

$0022-5223 / \$ 36.00$

Copyright (C) 2016 by The American Association for Thoracic Surgery

http://dx.doi.org/10.1016/j.jtcvs.2016.06.048

The report by Quinn and colleagues ${ }^{1}$ provides a comparison of cryopreserved (CP) homograft pulmonary valves with pulmonary homograft valves that were bioengineered (BE) by decellularization and then conditioned with a unique solution of fatty alcohol containing human hyaluronin immediately before implantation in growing sheep. After 6 months, the authors found cellular ingrowth into both the $\mathrm{BE}$ and $\mathrm{CP}$ valved conduit grafts, but the extent of surface coverage of the BE valves was greater. The $\mathrm{BE}$ valves had more extensive ingrowth of cells with endothelial and interstitial cell markers compared with the $\mathrm{CP}$ valves. There was good mobility of leaflets in both groups, although there was pannus ingrowth on both sets of valves. Minimal calcification was noted on the BE valve leaflets. Leaflet coaptation was better in the BE valves compared with the $\mathrm{CP}$ valves, although it remained less than normal in controls, and the increase in annular diameter was similar in both the $\mathrm{BE}$ valves and the $\mathrm{CP}$ valves compared with normal controls after 6 months of somatic growth of the animals. Pulmonary valvular

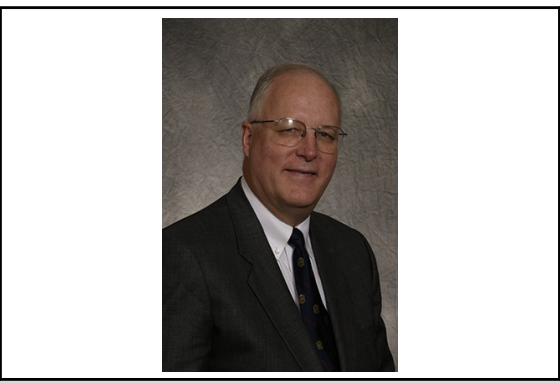

John E. Mayer, Jr, MD

\section{Central Message}

Progress has been made, but significant work remains for the successful development of tissue engineered heart valves.

See Articles page 1156 and 1197.

See Editorial Commentaries page 1200 and 1202 .

regurgitation at 6 months was related to the coaptation measurements, and the authors speculate that the increase in annular diameter without a commensurate increase in leaflet dimensions resulted in the decrease in coaptation surface area. The authors carefully refrained from invoking "growth" as the mechanism for the increase in annular diameter, and they report very low systolic pressure gradients even with pharmacologically increased cardiac 


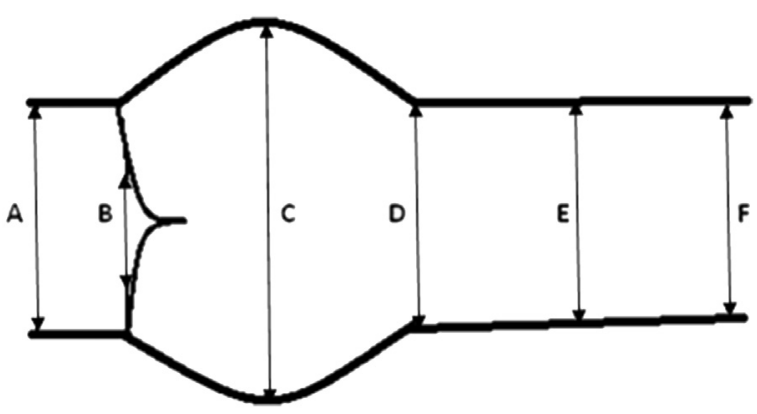

FIGURE E1. Anatomic diagram of a pulmonary valved conduit with cross-sectional arrows indicating the measurement locations: RVOT (A), annulus/proximal suture line (B), mid-sinus (C), sinotubular junction (D), mid-conduit (E), and prebifurcation pulmonary artery/distal suture line $(\mathrm{F})$. Diameters are measured at peak expansion.

A

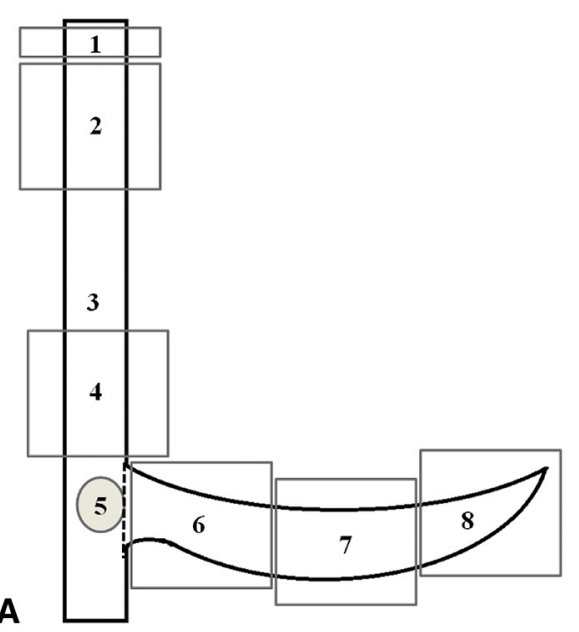

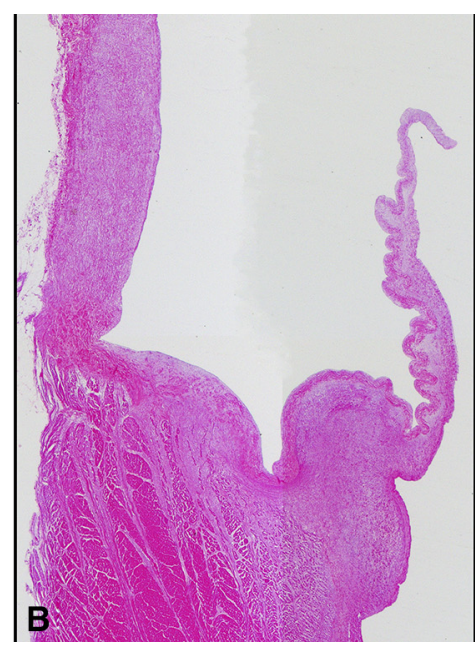

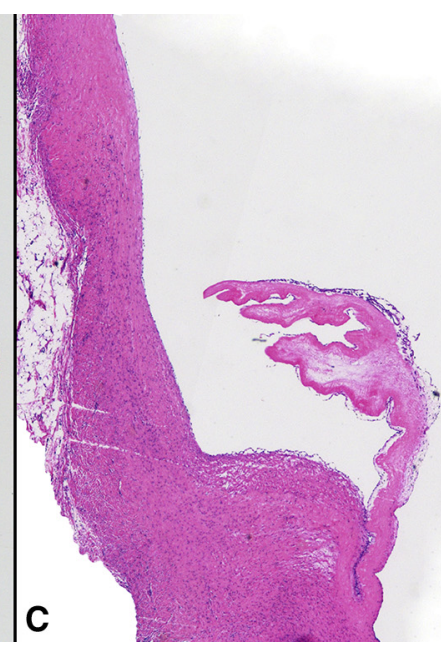

FIGURE E2. A, Longitudinal section of a sinus of a pulmonary valved conduit with boxes indicating areas sampled for decellularization verification (1) and cell density (2, pulmonary artery; 4, sinus; 5, sub-base; 6, cusp base; 7, mid-cusp; 8, distal cusp). Sinotubular junction (3) is indicated for anatomic reference. B, Representative decellularized, unimplanted ovine pulmonary valve $(\mathrm{H} \& \mathrm{E}, 25 \times)$ demonstrating adequate cell removal and anatomic structures. C, Explanted ovine BEPV $(\mathrm{H} \& \mathrm{E}, 25 \times)$ demonstrating recellularization of the sub-base and cusp base regions, with progressively decreasing cellularity toward the distal portion of the cusp. 


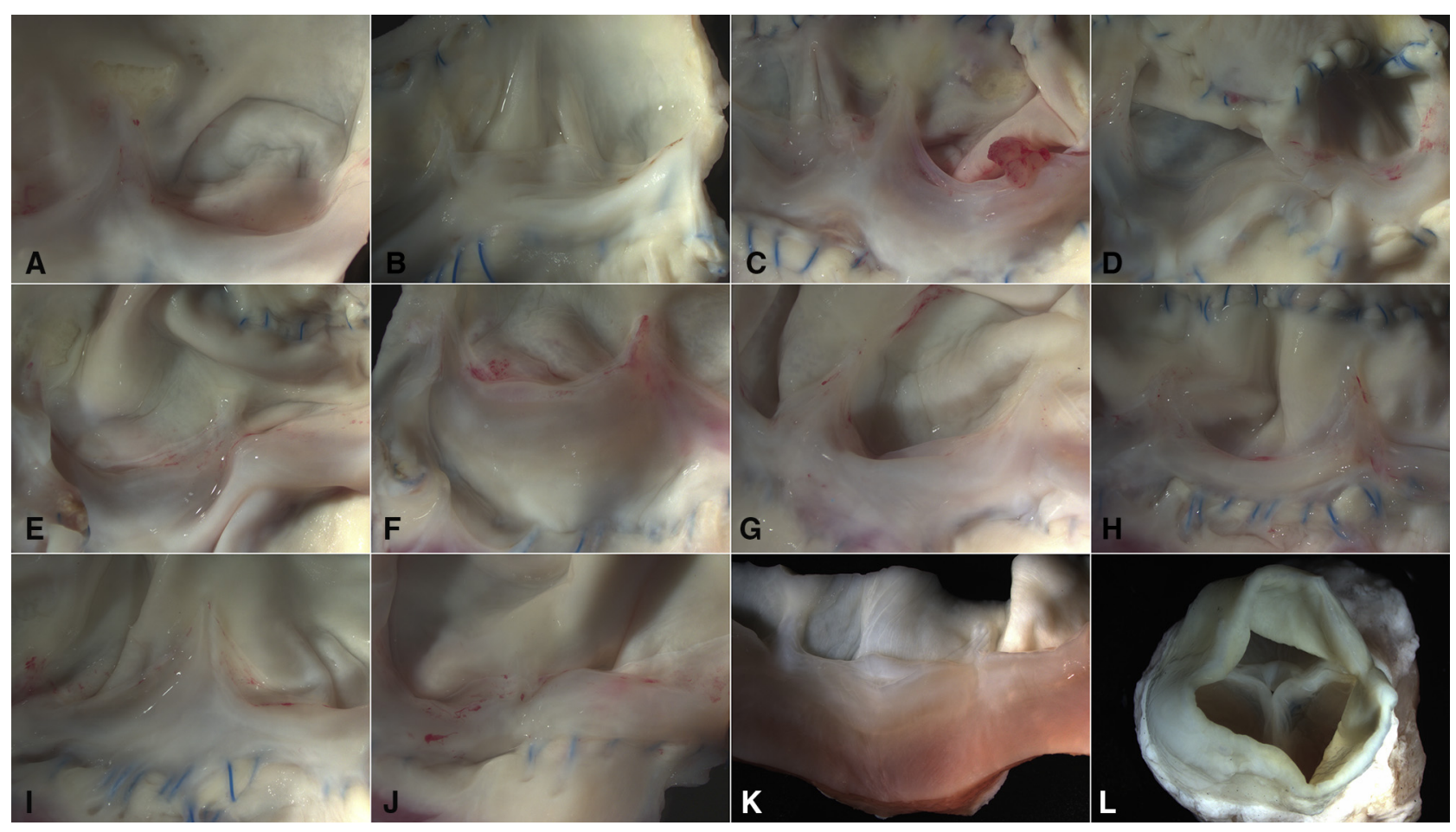

FIGURE E3. Macroscopic images of the CryoVs (A-C) and BEPVs (D-J) at explant. Cusps are thin and transparent, with minor fibrous sheathing and minimal thrombus/fibrin stranding. One CryoV cusp presented with a small nodule, likely calcified thrombus (no organisms visible in micrograph), in addition to visible calcified plaques on the sinus walls (C). This likely represents initial stages of Cryo calcific degradation. $\mathrm{K}$ and $\mathrm{L}$, Unimplanted BEPV images are included for reference.
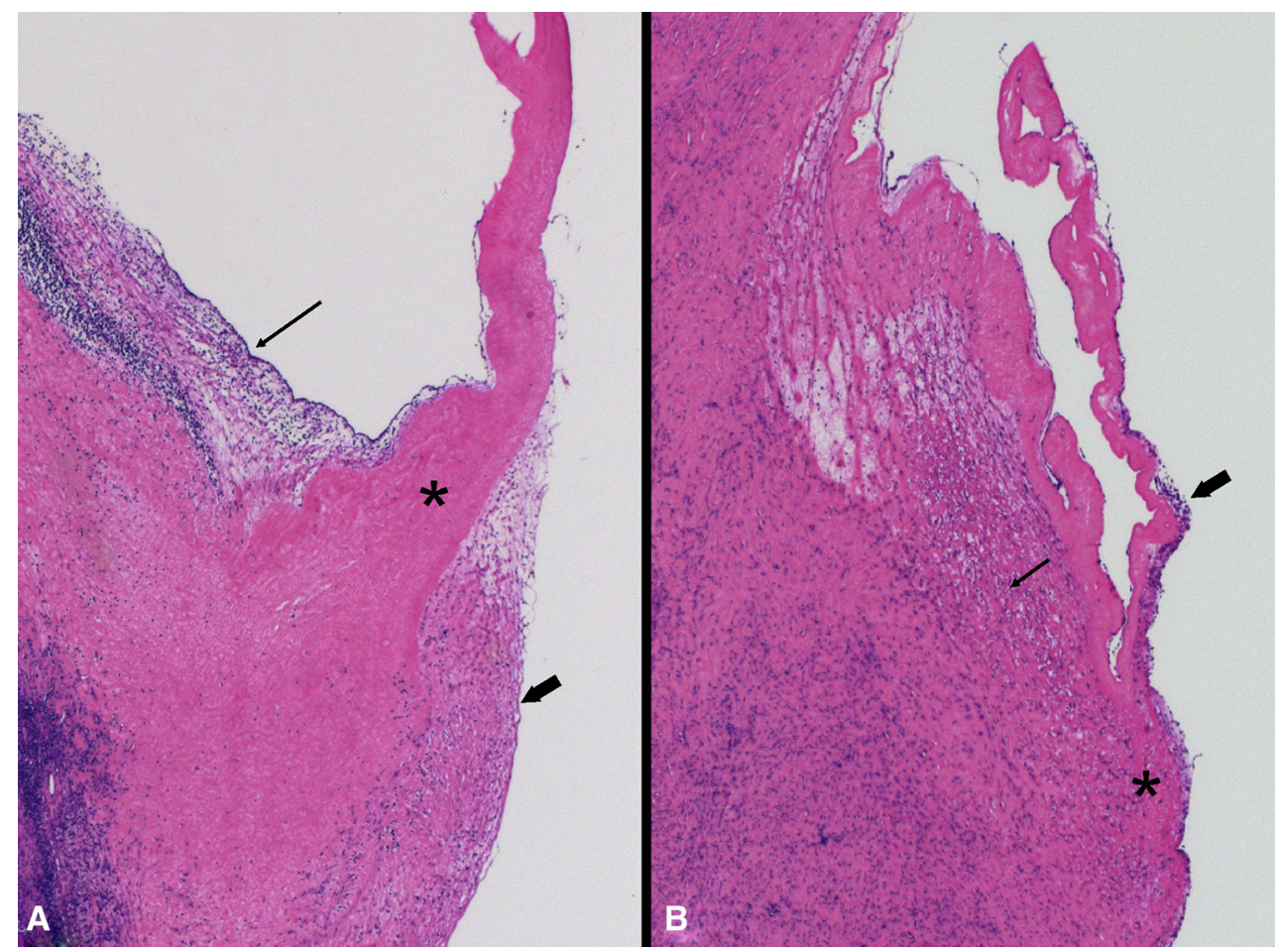

FIGURE E4. A, In a CryoV, note fibrous sheath (pannus) formation on the outflow portion of the sinus (thin arrow) and cusp base, as well as the inflow portion of the cusp and subvalvular lumen (thick arrow). B, In a BEPV, pannus is observed on the inflow portion of the cusp base (thick arrow), but not in the outflow region. Note the recellularization of the BEPV sinus wall (thin arrow). *Cusp origin. 
TABLE E1. Cardiac output and peak and mean gradients measured across the pulmonary and aortic valves during dobutamine stress echocardiography at explant

\begin{tabular}{|c|c|c|c|c|c|c|c|c|c|c|c|c|c|c|c|c|}
\hline \multirow[b]{4}{*}{ Variable } & \multicolumn{4}{|c|}{ CryoV $(n=3)$} & & \multicolumn{4}{|c|}{$\operatorname{BEPV}(n=7)$} & \multicolumn{5}{|c|}{ Native $(n=3)$} & \multirow{3}{*}{\multicolumn{2}{|c|}{$\begin{array}{c}P \text { value, } \\
0 \mu \mathrm{g} / \mathrm{kg} / \mathrm{min}\end{array}$}} \\
\hline & \multicolumn{2}{|c|}{$0 \mu / \mathrm{kg} / \mathrm{min}$} & \multicolumn{2}{|c|}{$2 \mu / \mathrm{kg} / \mathrm{min}$} & & \multicolumn{2}{|c|}{$0 \mu / \mathrm{kg} / \mathrm{min}$} & \multicolumn{2}{|c|}{$2 \mu / \mathrm{kg} / \mathrm{min}$} & \multicolumn{3}{|c|}{$0 \mu / \mathrm{kg} / \mathrm{min}$} & \multicolumn{2}{|c|}{$2 \mu / \mathrm{kg} / \mathrm{min}$} & & \\
\hline & $\begin{array}{c}\text { Median } \\
(25 \%-75 \%\end{array}$ & & $\begin{array}{l}\text { Median } \\
(25 \%-75 \%\end{array}$ & & & $\begin{array}{c}\text { Median } \\
(25 \%-75 \%\end{array}$ & & $\begin{array}{c}\text { Median } \\
(25 \%-75 \%\end{array}$ & & & $\begin{array}{c}\text { Median } \\
(25 \%-75 \%\end{array}$ & & $\begin{array}{c}\text { Median } \\
(25 \%-75 \%\end{array}$ & & & \\
\hline & $\begin{array}{l}\text { interquartile } \\
\text { range) }\end{array}$ & $\begin{array}{r}\text { Mean } \\
(\text { SEM) } \\
\end{array}$ & $\begin{array}{c}\text { interquartile } \\
\text { range) }\end{array}$ & $\begin{array}{l}\text { Mean } \\
\text { (SEM) }\end{array}$ & $P$ & $\begin{array}{l}\text { interquartile } \\
\text { range) }\end{array}$ & $\begin{array}{l}\text { Mean } \\
\text { (SEM) }\end{array}$ & $\begin{array}{l}\text { interquartile } \\
\text { range) }\end{array}$ & $\begin{array}{r}\text { Mean } \\
(\text { SEM) }\end{array}$ & $P$ & $\begin{array}{l}\text { interquartile } \\
\text { range) }\end{array}$ & $\begin{array}{c}\text { Mean } \\
(\text { SEM })\end{array}$ & $\begin{array}{l}\text { interquartile } \\
\text { range) }\end{array}$ & $\begin{array}{c}\text { Mean } \\
(\text { SEM) }\end{array}$ & $P$ & $\begin{array}{l}\text { vs } 2 \mu \mathrm{g} / \\
\mathrm{kg} / \mathrm{min}\end{array}$ \\
\hline
\end{tabular}

RVOT4.68 (4.39-4.83)4.59 (0.26)5.47 (5.45-6.24)5.97 (0.52).1094.86 (3.98-4.89)4.31 (0.33)7.88 (7.12-8.15)7.62 (0.40).0183.85 (3.82-4.33)4.15 (0.33)5.92 (5.66-6.08)5.85 (0.25).109 Peak gradient, $\mathrm{mm} \mathrm{Hg}$

PV $\quad 3.00(3.00-3.00) 3.00(0.00) 5.00(4.00-5.50) 4.67(0.88) .1802 .00(2.00-3.00) 2.57(0.30) 7.00(6.00-7.00) 6.29(0.42) .0163 .00(2.50-3.00) 2.67(0.33) 7.00(5.00-7.50) 6.00(1.53) .109$

$\mathrm{AV} \quad 3.00(2.50-3.50) 3.00(0.58) 6.00(4.00-8.00) 6.00(2.31) .2852 .00(2.00-3.00) 2.43(0.20) 6.00(5.00-7.00) 6.14(0.71) .0184 .00(4.00-4.00) 4.00(0.00) 6.00(6.00-7.00) 6.67(0.67) .102 \quad .729$ Mean gradient, $\mathrm{mm} \mathrm{Hg}$

PV $2.00(2.00-2.00) 2.00(0.00) 3.00(2.00-3.00) 2.33(0.67) .5641 .00(1.00-1.50) 1.29(0.18) 4.00(3.00-4.00) 3.43(0.30) .0161 .00(1.00-1.50) 1.33(0.33) 4.00(3.00-4.00) 3.33(0.67) .109$ $\mathrm{AV} \quad 2.00(1.50-2.50) 2.00(0.58) 3.00(2.00-4.00) 3.00(0.12) .2762 .00(1.00-2.00) 1.57(1.15) 3.00(2.50-3.50) 3.00(0.31) .0392 .00(2.00-2.00) 2.00(0.00) 3.00(3.00-3.50) 3.33(0.33) .102 \quad .929$

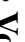

$C r y o V$, Cryopreserved pulmonary valve; $B E P V$, bioengineered replacement pulmonary valve; $S E M$, standard error of the mean; $R V O T$, right ventricular outflow tract; $P V$, pulmonary valve; $A V$, aortic valve. 
TABLE E2. Correlation analysis of measurements after 6 mo

\begin{tabular}{|c|c|c|c|c|c|c|}
\hline Variable & Peak gradient & Mean gradient & Conduit wall thickness & Regurgitation & Leaflet thickness & $\%$ Coaptation \\
\hline \multicolumn{7}{|c|}{ Peak gradient } \\
\hline$r$ & 1 & $0.742 *$ & 0.507 & -0.152 & 0.520 & 0.136 \\
\hline$P$ value & & .004 & .077 & .620 & .068 & .6578 \\
\hline \multicolumn{7}{|c|}{ Mean gradient } \\
\hline$r$ & $0.742 *$ & 1 & $0.627 *$ & 0.353 & 0.5098 & -0.124 \\
\hline$P$ value & .004 & & .022 & .237 & .076 & .687 \\
\hline \multicolumn{7}{|c|}{ Conduit wall thickness } \\
\hline$r$ & 0.507 & $0.627 *$ & 1 & 0.046 & 0.413 & -0.134 \\
\hline$P$ value & .077 & .022 & & .881 & .160 & .663 \\
\hline \multicolumn{7}{|c|}{ Regurgitation } \\
\hline$r$ & -0.152 & 0.353 & 0.046 & 1 & 0.184 & $-0.611^{*}$ \\
\hline$P$ value & .620 & .237 & .881 & & .547 & .026 \\
\hline \multicolumn{7}{|c|}{ Leaflet thickness } \\
\hline$r$ & 0.520 & 0.508 & 0.413 & 0.184 & 1 & -0.457 \\
\hline$P$ value & .068 & .076 & .160 & .547 & & .116 \\
\hline \multicolumn{7}{|c|}{$\%$ coaptation } \\
\hline$r$ & 0.136 & -0.124 & -0.134 & $-0.611^{*}$ & -0.457 & 1 \\
\hline$P$ value & .658 & .687 & .663 & .026 & .116 & \\
\hline
\end{tabular}

